\title{
Gamification Elements for Learning Applications
}

\author{
Firas Layth Khaleel ${ }^{\#}$, Noraidah Sahari@ Ashaari ${ }^{*}$, Tengku Siti Meriam Tengku Wook ${ }^{\#}$, Amirah Ismail ${ }^{*}$ \\ ${ }^{*}$ Research Center for Software Technology and Management, Faculty of Information Science and Technology, \\ Universiti Kebangsaan Malaysia, Bangi, Selangor, 43600, Malaysia \\ E-mail: ukmp69617@siswa.ukm.edu.my,nsa@ukm.edu.my, tsmeriam @ukm.edu.my,amirahismail@ukm.edu.my \\ ${ }^{\#}$ Computer Science Department, College of Computers Science and Mathematics, Tikrit University, 00964, Iraq \\ E-mail: Firas_layth@tu.edu.iq
}

\begin{abstract}
Gamification technique is getting popular to be implemented in learning or training application. It is referred to the use of game elements or game thinking in a non-game context in order to increase engagement between students and learning application. Since there are many elements of games that are identified from previous works, this study focuses on game elements from Gamification technique that positively affect learning when applied to a learning application. Therefore, the objectives of this research are to identify game elements that can be gamified in a learning application; and to verify those elements by multiple users (gamers, students, and experts). Suitable game elements are identified through literature reviews. Two approaches are used to verify these elements; interview experts and administer a survey to gamers and students. The finding of this study suggests the use of a group of game elements with three aims, (1) increase the level of fun and entertainment; (2) motivate students to challenge each other; and (3) improve gaming and learning skills. In a further study, these elements will be implemented in a learning application and its effectiveness shall be tested.
\end{abstract}

Keywords — gamification; game elements; game design; game mechanic; game technique; multi-users

\section{INTRODUCTION}

Gamification refers to the use of game elements in a nongame context to increase the engagement between humans and computers and to solve problems effectively [1], [2], [3]. [4] defined Gamification as a process of game thinking and game mechanics that engages users and solves problems. [5] argues that Gamification can be thought of as using pieces of games to motivate learners, but the real definition of Gamification involves using game-based mechanics, aesthetics, and game thinking to engage people, motivate action, promote learning, and solve problems. By 2014, a gamified service for consumer goods marketing and customer retention would become as important as Facebook, eBay, or Amazon; and more than $70 \%$ of Global 2000 organizations would have at least one gamified application. [6] predicted that by 2015 , more than $50 \%$ of organizations that manage innovation processes will gamify their processes. Gamification is an integral part of an application because it can ensure the effectiveness of its usage as demonstrated by [7]. Within the learning environment, the benefits of Gamification elements cannot be ignored because the main goal is to increase students's engagement, motivation, and understanding using a fun and enjoyable learning environment, thereby yielding high students performance.

Many researchers have attempted to summarize game elements; [13], [14], [15] investigated the elements of game mechanics only. [8] has investigated elements of game mechanics and game dynamics, but [18] added the motives field to these elements to better explain them; a more detailed discussion is presented in Section 2 of this paper. The major focus of this study is on selecting suitable game elements because there are a lot of game elements introduced in previous research. Therefore, the objective of this paper is to discuss the derivation of game elements that will induce positive effects when applied to a learning application. The summarized group of game elements would then be verified by multi-users via qualitative and quantitative methods.

Section I of this paper explains a brief description of the major focus of this study and describes the objectives and how they are achieved. Section II summarizes and critically analyzes related works. Section III describes the methods used in this study. Section IV presents the analysis of results and discusses the results based on multiple perspectives, and finally, the conclusion of this study is presented in Section V.

In this section, we determine all game elements and then attempt to establish Gamification elements. According to [8], 
games generally have two main elements, namely, game mechanics (points, level, badges, virtual good or gifts or leaderboard) and game dynamics (reward, status, achievement, self-expression or altruism).

In the previous work of [8], the focus was on two main points; the first was to apply the game elements in a social learning environment only, which is insufficient for learning applications. The second point is the effect of these elements on the player's emotions, as game mechanics are the rules and rewards of the game which intended to evoke strong emotions from the player, whereas game dynamics are the desires and motivations that will lead to these emotions. These effects can be adapted for other kinds of learning applications.

During the field experiment, [9] mentioned that game mechanics involve badges, points, and Leaderboards. Game elements could be extracted from different kinds of games, such as serious games, video games, and social games [8, 10]. [11], [12] mentioned that game mechanics, such as point and level and game design, have a scoring scheme to improve participation in a requirement elicitation process. Table 1 summarizes game mechanics elements based on [13], [14], [15].

In their papers, [13], [14, [15] summarize the key aspects of game mechanics such as a player's possible actions in the game system, player's actions design document, and a game system's set of rules. However, only Game mechanics elements that increase the engagement and motivation of user will be considered in learning applications.

Various studies have focused on educational computer games and their effect on students [16], [17]. [18] consolidated a number of sources toward the development of a service-based Gamification strategy. These "gamified service bundles" are comprised of a core offering based on desired usage objectives and a Gamification layer made up of game design elements.
TABLE I

GAME MECHANICS ELEMENTS

\begin{tabular}{|l|l|}
\hline \multicolumn{2}{|c|}{ Game mechanics elements } \\
\hline Achievement & Moral hazard of game play \\
\hline Behavioral contrast & Privacy \\
\hline Cascading information & Real-time \\
\hline Companion gaming & Response \\
\hline Cross situational leader-boards & Shell game \\
\hline Envy & Virtual items \\
\hline Fixed interval reward schedules & Avoidance \\
\hline Fun once, fun always & Blissful productivity \\
\hline Loyalty & Communal discovery \\
\hline Modifiers & Countdown \\
\hline Pride & Endless games \\
\hline Ratio reward schedules & Extinction \\
\hline Reinforcer & Free lunch \\
\hline Rolling physical goods & Lottery \\
\hline Urgent optimism & Micro leader-boards \\
\hline Viral game mechanics & Ownership \\
\hline Appointment dynamic & Progression dynamic \\
\hline Behavioral momentum & delayed mechanics \\
\hline Chain Schedules & Reward schedules \\
\hline Contingency & Social fabric of games status \\
\hline Disincentives & $\begin{array}{l}\text { Variable ratio reward } \\
\text { schedule }\end{array}$ \\
\hline Fixed ratio reward schedule & $\begin{array}{l}\text { Variable interval reward } \\
\text { schedules }\end{array}$ \\
\hline Interval reward schedules & Epic meaning \\
\hline Meta game & \\
\hline & \\
\hline
\end{tabular}

Also, in [18], the framework is meant to highlight how Gamification can operate on intrinsic and extrinsic motivators to bring about behavioral change and reframe activities such as learning. Table 2 presents the Game design elements, dynamics, and motives from [18].

Table 2 highlights the most important game-design elements but it can be observed that the elements of game design cannot be merged with the elements of game mechanics and dynamics. In addition, previous researchers have determined each element separately [8], [13], [14], [15], [20], [21], [22].

TABLE II

GAME DESIGN ELEMENTS, DYNAMICS, AND MOTIVES [18]

\begin{tabular}{|c|c|c|}
\hline \multicolumn{2}{|c|}{ Game Design Element } & \multirow{2}{*}{ Motives } \\
\hline Game Element: Mechanics & Game Element: Dynamics & \\
\hline Documentation of behavior & Exploration & Intellectual curiosity \\
\hline Scoring systems, badges, trophies & Collection & Achievement \\
\hline Rankings & Competition & Social recognition \\
\hline Ranks, levels, reputation points & Acquisition of status & Social recognition \\
\hline Group tasks & Collaboration & Social exchange \\
\hline Time pressure, tasks, quests & Challenge & Cognitive stimulation \\
\hline Avatars, virtual worlds, virtual trade & Development/organization & Self-determination \\
\hline
\end{tabular}

[19] developed a framework based on self-determination theory, in particular, the concepts of autonomy, competence and social relatedness. The framework is divided into four parts; the first is identification of the main objective or outlining the reasons behind the use of Gamification; the second is identification of the transversal objective, or what intrinsically motivating factors the system seeks to provide, and the third involves determining what game mechanics will be used based on how they relate to the concepts of selfdetermination (see Table 3). The final part of the framework involves how to evaluate the framework in applied systems. As of yet, this framework has not been applied. 
TABLE III

CONCEPTS OF GAME ELEMENTS USING THE SELF-DETERMINATION THEORY [19]

\begin{tabular}{|l|l|l|}
\hline \multicolumn{1}{|c|}{ Autonomy } & \multicolumn{1}{c|}{ Competence } & \multicolumn{1}{c|}{ Relation } \\
\hline Profiles, avatars, & Positive feedback, & Groups, \\
macros, & optimal challenge, & messages, blogs, \\
configurable & progressive & connection to \\
interface, alternative & information, & social networks, \\
activities, privacy & intuitive controls, & chat. \\
control, notification & points, levels, & \\
control. & leaderboards. & \\
\hline
\end{tabular}

Consequently, based on [20], [21], [22], [26] this study aims to employ three Gamification elements such as game mechanics (dashboard and progress bar), game design (using a badge as a reward), and game techniques (Leaderboards showing scores or marks) as presented in Figure 1. These elements would be applied in a learning environment in order to design an enjoyable, motivating and effective learning content presentation.

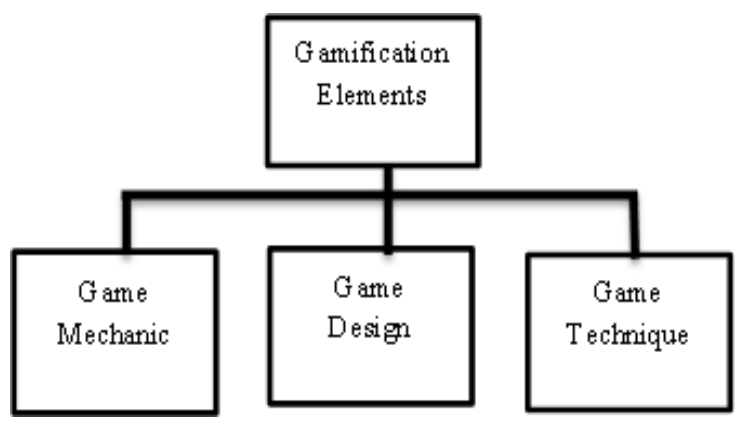

Fig. 1 Gamification elements

To confirm or verify the suitable elements, the subsequent section will explain the method and the findings.

\section{MATERIALS AND METHOdS}

This study was carried out via two kinds of research methods i.e. the qualitative and quantitative methods. This study used an interview approach to assess the perspective of experts. To investigate the perspectives of real users (gamers and students), a survey approach using instruments such as questionnaires were used. This is further elaborated upon in the subsequent section.

A qualitative method via an interview approach was conducted at the Faculty of Information Science and Technology, Universiti Kebangsaan Malaysia (UKM), and Tikrit University (TU). The purpose of the interview was to verify the game elements for learning applications. The interview began with an explanation of the purpose of the research and why the interview method was used. For Tikrit University, the interview was conducted over the phone (Viber) and via Skype. A total of 5 experts were interviewed based on [23], [24], [25]. Each interview took 1-2 hours, during which all game elements were asked, as suggested by [8], [13], [14], [15], [18], [19].

A quantitative method using a survey approach was employed. The questionnaire began with an explanation of the purpose of the investigation and why the questionnaire method was used. The purpose of the questionnaire was to gain feedback about the selected elements from real users. A total of 60 participants (30 gamers from South City Computer Game Hall and 30 undergraduate/ postgraduate students from Universiti Kebangsaan Malaysia, Universiti Putra Malaysia, and Universiti Tenaga Nasional, aged between 21 to 31 years) were invited to answer the questionnaire. All the students were enrolled in Semesters 2 (2013-2014 session), semester 1/2 (2014-2015 session), and semester 1 (2015-2016 session).

All questions, which were based on previous studies and interviews [28], [29], are shown in Table 1-3. Prior to answering the questionnaire, Gamification, and its elements were explained to all participants. During the survey, each respondent is required to write a comment or suggestion about the usage of game elements in the Gamification technique towards the enhancement of student learning.

\section{A. Data Collection}

Interviews were conducted in person as a face to face interview in UKM and over the telephone (Viber). The interview questions were structured and adopted from previous work, the details of interview questions as shown in Table 4.

TABLE IV

INTERVIEW QUESTIONS

\begin{tabular}{|c|l|}
\hline No & \multicolumn{1}{|c|}{ Question } \\
\hline 1 & Do you know about gamification technique? \\
\hline 2 & $\begin{array}{l}\text { Based on your experiences, what is a game } \\
\text { element? }\end{array}$ \\
\hline 3 & $\begin{array}{l}\text { Do you think game elements can support the } \\
\text { learning? Please spicify. }\end{array}$ \\
\hline 4 & $\begin{array}{l}\text { I summarized a group of game elements based on } \\
\text { previous work; can you select the most elements } \\
\text { suitable for learning? }\end{array}$ \\
\hline 5 & $\begin{array}{l}\text { In your opinion, what is the impact of these game } \\
\text { elements on learning? }\end{array}$ \\
\hline 6 & $\begin{array}{l}\text { Based on your experiences, How these elements } \\
\text { increase the effectiveness, interest, and motivation } \\
\text { for students in learning }\end{array}$ \\
\hline
\end{tabular}

Survey was conducted in this study using questionnaire Likert scale, distributed by self-administration to gamers and students. The questions of the survey are based on the outcomes of interviews.

The main purpose that leads this study to conducted two perspectives of gamers and students (undergraduate and postgraduate) was to verify by existing generation and to compare between their viewpoints of the same elements.

\section{B. Data Instrument}

The evaluation system in this research had five likert scales measure levels of agreements, namely, strongly disagree, disagree, quiet agree, agree, and strongly agree. For each question, the students were required to select one scale that reflects their belief.

\section{RESULTS AND DISCUSSIONS}

Results of both approaches are discussed in this section.

\section{A. Interview Findings}


The results of the analysis also revealed that the interviewed participants gave positive answers in support of, and to solidify any issues; a few examples are illustrated below :

Interviewee 1: "The most impact of all elements have a positive effect on the understanding and learning of students as well as gamers..."

Interviewee 2: "Example in the paper just have 2 colours (black and white) if you have the paper with extra 4-5 colours (highlight) that will increase the attention.

So these elements increase engagement, motivation, effectiveness, interesting, entertainment, fun, etc. through the attention..."

Interviewee 3: "I believe that game elements have a strong power to increase the effectiveness, motivation and interesting of the student if they organized well...

Because that led to creating challenges, competition among students... at the end, these elements have a positive effect on student engagements..."

Finally, Table 5 summarized the respondents for each one based on the game elements of its functionality. Based on Table 5, the suggestions provided by the interviewee are analyzed and summarized. In general, all interviewed experts provided agreeable feedback on the selected game elements and they categorized the elements based on their functionality, as explained:

- Achievement (Points, Scoring system, and Stars),

- Virtual gifts (Badge),

- Reward schedules (Top 10 and Leaderboard),

- Status (Result, Report, Dashboard, Percentage of competency and Progress Bar),

- Real-time (Stage, Level, and Countdown),

- Profiles (Information, Pictures and/or Avatars).

TABLE V

INTERVIEWEE SUGGESTION

\begin{tabular}{|c|c|c|}
\hline Interviewee & The recondense & $\begin{array}{c}\text { Game elements } \\
\text { (functionality) }\end{array}$ \\
\hline 1 & $\begin{array}{l}\text { These elements must be } \\
\text { classified based on usability } \\
\text { and functionality of each } \\
\text { one, for example, use a } \\
\text { reward system for students } \\
\text { such as Top } 10 \text { and } \\
\text { Leaderboard where their } \\
\text { names or pictures are } \\
\text { displayed based on points or } \\
\text { scores they have collected }\end{array}$ & $\begin{array}{l}\text { Top } 10 \\
\text { and } \\
\text { Leaderboard }\end{array}$ \\
\hline 2 & $\begin{array}{l}\text { Yes, of course, I agree with } \\
\text { all the game elements for } \\
\text { this study, but there is no } \\
\text { need to reuse all of them. } \\
\text { We only need to reuse } \\
\text { elements that are proven to } \\
\text { have a strong effect on the } \\
\text { motivation of the student } \\
\text { when they learn or during } \\
\text { game play such as the real- } \\
\text { time feature, which } \\
\text { promotes gamers or students } \\
\text { to think quickly to reach the } \\
\text { next stage and/or level } \\
\text { whilst having to deal with a }\end{array}$ & $\begin{array}{l}\text { Stage or level } \\
\text { and } \\
\text { Countdown }\end{array}$ \\
\hline
\end{tabular}

\begin{tabular}{|c|c|c|}
\hline Interviewee & The recondense & $\begin{array}{l}\text { Game elements } \\
\text { (functionality) }\end{array}$ \\
\hline & real-time countdown & \\
\hline 3 & $\begin{array}{l}\text { I believe that certain game } \\
\text { elements have a strong } \\
\text { effect in challenging } \\
\text { students, e.g. Result, Report, } \\
\text { Dashboard, Percentage of } \\
\text { competency, and Progress } \\
\text { Bar. } \\
\text { On the other hand, the } \\
\text { Profile information with the } \\
\text { player progress in each } \\
\text { level, stage or change in } \\
\text { badges or Avatars are quite } \\
\text { important for gamers and } \\
\text { students }\end{array}$ & $\begin{array}{l}\text { Result, Report, } \\
\text { Dashboard, } \\
\text { Percentage of } \\
\text { competency, } \\
\text { badge, avatar } \\
\text { and Progress } \\
\text { Bar }\end{array}$ \\
\hline 4 & $\begin{array}{l}\text { Yes, of course, you must } \\
\text { use a big Leaderboard that } \\
\text { includes all participants and } \\
\text { a Top } 10 \text { or Top } 20 \text { for the } \\
\text { best participants } \\
\text { Also, the results must be } \\
\text { presented in the form of a } \\
\text { Progress Bar when } \\
\text { something needs to be done } \\
\text { or a particular goal must be } \\
\text { achieved, and so on }\end{array}$ & $\begin{array}{l}\text { Leaderboard, } \\
\text { Top } 10 \text { or Top } \\
20 \\
\text { Progress Bar }\end{array}$ \\
\hline 5 & $\begin{array}{l}\text { I can't say for example } \\
\text { element one is suitable for } \\
\text { particular things, because it } \\
\text { depend on the functionality } \\
\text { for each game elements } \\
\text { such as: If I want to be used } \\
\text { for achievement purpose } \\
\text { such as (Points, Scoring } \\
\text { system, and Stars); Virtual } \\
\text { gifts (Badge); Reward } \\
\text { schedules (Top } 10 \text { and } \\
\text { Leaderboard); Status } \\
\text { (Result, Report, Dashboard, } \\
\text { Percentage of competency } \\
\text { and Progress Bar; Real-time } \\
\text { (Stage, Level and } \\
\text { Countdown); Profiles } \\
\text { (Information, Pictures } \\
\text { and/or Avatars). }\end{array}$ & $\begin{array}{l}\text { Points, Scoring } \\
\text { system, Stars, } \\
\text { Badge, Top 10, } \\
\text { Leaderboard, } \\
\text { Result, Report, } \\
\text { Dashboard, } \\
\text { Percentage of } \\
\text { competency, } \\
\text { Progress Bar, } \\
\text { Stage, Level, } \\
\text { Countdown, } \\
\text { Information, } \\
\text { Pictures and/or } \\
\text { Avatars. }\end{array}$ \\
\hline
\end{tabular}

\section{B. Survey Findings}

Table 6 shows the demographic information of participants as well as gameplay details. This has led to the study of the intersections of game elements between the types of game and the game environments preferred from two perspectives. Then, this study reuses a group of game elements from the literature review, which has been verified based on the expert interview, resulting in the same game elements preferred by gamers and students.

From the gamers' perspective, the one thing they consider the most important when playing a game is the increase in the level of fun and entertainment; only 12 students liked playing games for this purpose. In the case of other benefits of playing games, only two gamers played games to increase their motivation to challenge other students but 8 students liked playing games simply to increase their motivation. The 
last benefit of playing games is elaborated in the study's results. Ten students and three gamers played games to improve their skill at gaming and learning. Finally, this study verified these elements based on the purpose of playing games from the two-perspective evaluation.

Subsequently, the perspective of real users is evaluated in terms of fun and entertainment; motivation for students to challenge each other; and improvement of gaming and learning skills, as shown in Table 7. The evaluation used dichotomous agreement scale. The scale is used to measure levels of agreements for each game element. The gamers and students were required to evaluate each game element that reflects their belief for using these elements i.e. to gamify any learning application based on the three measurements of fun and entertainment, the motivation for students to challenge each other; and improvement of gaming and learning skills, as shown in Table 7.

TABLE VI

DEMOGRAPHIC INFORMATION AND GAME PLAY DETAILS

\begin{tabular}{|c|c|c|c|c|}
\hline \multirow{2}{*}{$\begin{array}{ll}\text { Characteristics of } \\
\text { Gender } \\
\end{array}$} & \multicolumn{2}{|c|}{$\begin{array}{c}\text { Gamers } \\
(\mathbf{N}=\mathbf{3 0})\end{array}$} & \multicolumn{2}{|c|}{$\begin{array}{c}\text { Students } \\
(\mathbf{N}=30)\end{array}$} \\
\hline & Frequency & Percent & Frequency & Percent \\
\hline Male & 27 & 90 & 25 & 83.33 \\
\hline Female & 3 & 10 & 5 & 16.67 \\
\hline \multicolumn{5}{|l|}{ Age } \\
\hline $21-25$ years old & 27 & 90 & 23 & 76.67 \\
\hline $25-30$ years old & 2 & 6.67 & 4 & 13.33 \\
\hline Above 30 years old & 1 & 3.33 & 3 & 10 \\
\hline \multicolumn{5}{|l|}{ Qualification } \\
\hline Bachelor's degree & 29 & 96.67 & 30 & 100 \\
\hline Master degree & 1 & 3.33 & 0 & 0 \\
\hline Ph.D. and above & 0 & 0 & 0 & 0 \\
\hline \multicolumn{5}{|l|}{ Do you like to play a game? } \\
\hline Yes & 30 & 100 & 30 & 100 \\
\hline No & 0 & 0 & 0 & 0 \\
\hline \multicolumn{5}{|l|}{ How many hours per day? } \\
\hline $0-1$ & 0 & 0 & 10 & 33.34 \\
\hline $2-3$ & 0 & 0 & 12 & 40 \\
\hline $4-5$ & 1 & 3.33 & 7 & 23.33 \\
\hline More than 5 & 29 & 96.67 & 1 & 3.33 \\
\hline \multicolumn{5}{|l|}{ What is the purpose and benefit of playing a game? } \\
\hline Increase the fun and entertainments & 25 & 83.33 & 12 & 73.33 \\
\hline Motivation to challenge among students & 2 & 6.67 & 8 & 23.34 \\
\hline Improve the skill of gaming and learning & 3 & 10 & 10 & 3.33 \\
\hline Other & 0 & 0 & 0 & 0 \\
\hline \multicolumn{5}{|l|}{ What is the type of games that you prefer to play? } \\
\hline Racing game & 4 & 13.33 & 2 & 6.67 \\
\hline sports game & 17 & 56.67 & 16 & 53.33 \\
\hline Fighting games & 3 & 10 & 4 & 13.33 \\
\hline Strategy games & 6 & 20 & 8 & 26.67 \\
\hline \multicolumn{5}{|c|}{ What are the environments that prefer to playing a game? } \\
\hline Computer/PC-based DVD-ROM or CDROM & 29 & 96.67 & 27 & 90 \\
\hline $\begin{array}{c}\text { Mobile Computer, Mobile Phones, Personal } \\
\text { Digital Assistants (PDA) }\end{array}$ & 1 & 3.33 & 3 & 10 \\
\hline \multicolumn{5}{|l|}{ What is your prefer to play } \\
\hline Individual & 12 & 40 & 6 & 20 \\
\hline Group play & 18 & 60 & 24 & 80 \\
\hline
\end{tabular}

In conclusion, the main purpose that leads this study to conducted two perspectives of gamers and students (undergraduate and postgraduate) was to verify by existing generation and to compare between them from their viewpoints. It was determined that all elements were agreed from all user perspectives because the result for each one is more than 4.0. High rate shows that respondents have common agreements in the game elements based on the analysis of Table 7. Recommendations are as follows:
- Gamers suggested using Points, Scoring system, and Stars to increase the level of fun and entertainment.

- Students suggested using Badges, Top 10, and a Leaderboard to increase motivation to for students to challenge each other.

- Finally, both perspectives suggested the rest of the elements such as Result, Report, Dashboard, Percentage of competency, Progress Bar, Stage, Level, Countdown, profile Information, Pictures, and Avatars, to improve gaming and learning skills. 
TABLE VII

Game Elements Evaluation Based On (GAmers, Students) For (1) Fun And Entertainments; (2) Motivation To Challenge Among Students; AND (3) IMPROVE THE SKILl OF GAMING AND LEARNING

\begin{tabular}{|c|c|c|c|c|c|c|}
\hline \multirow[t]{2}{*}{ Game elements } & \multicolumn{3}{|c|}{ Gamers } & \multicolumn{3}{|c|}{ Students } \\
\hline & $\begin{array}{c}\text { Fun and } \\
\text { entertainments }\end{array}$ & Motivation & $\begin{array}{l}\text { Improve } \\
\text { skill }\end{array}$ & $\begin{array}{c}\text { Fun and } \\
\text { entertainments }\end{array}$ & Motivation & $\begin{array}{c}\text { Improve } \\
\text { skill }\end{array}$ \\
\hline Achievement & Mean & Mean & Mean & Mean & Mean & Mean \\
\hline Points & 4.93 & 4.77 & 4.77 & 4.70 & 4.60 & 4.60 \\
\hline Scoring system & 4.83 & 4.77 & 4.80 & 4.67 & 4.60 & 4.73 \\
\hline Stars & 4.87 & 4.63 & 4.57 & 4.80 & 4.67 & 4.63 \\
\hline \multicolumn{7}{|l|}{ Virtual gifts } \\
\hline Badge & 4.43 & 4.47 & 4.57 & 4.47 & 4.87 & 4.37 \\
\hline \multicolumn{7}{|l|}{ Reward schedules } \\
\hline Top 10 & 4.63 & 4.37 & 4.37 & 4.33 & 4.83 & 4.40 \\
\hline Leaderboard & 4.53 & 4.63 & 4.40 & 4.57 & 4.80 & 4.47 \\
\hline \multicolumn{7}{|l|}{ Status } \\
\hline Result & 4.47 & 4.40 & 4.63 & 4.57 & 4.33 & 4.90 \\
\hline Report & 4.50 & 4.43 & 4.63 & 4.67 & 4.80 & 4.83 \\
\hline Dashboard & 4.53 & 4.33 & 4.60 & 4.37 & 4.60 & 4.80 \\
\hline $\begin{array}{l}\text { Percentage of } \\
\text { competency }\end{array}$ & 4.30 & 4.33 & 4.57 & 4.40 & 4.60 & 4.73 \\
\hline Progress Bar & 4.33 & 4.40 & 4.53 & 4.63 & 4.50 & 4.73 \\
\hline \multicolumn{7}{|l|}{ Real-time } \\
\hline Stage & 4.53 & 4.73 & 4.83 & 4.37 & 4.43 & 4.90 \\
\hline Level & 4.60 & 4.70 & 4.90 & 4.37 & 4.20 & 4.80 \\
\hline Countdown & 4.60 & 4.80 & 4.83 & 4.30 & 4.67 & 4.73 \\
\hline \multicolumn{7}{|l|}{ Profiles } \\
\hline Information & 4.47 & 4.57 & 4.80 & 4.43 & 4.60 & 4.80 \\
\hline Pictures & 4.70 & 4.50 & 4.87 & 4.60 & 4.63 & 4.77 \\
\hline Avatars & 4.53 & 4.47 & 4.77 & 4.57 & 4.53 & 4.73 \\
\hline
\end{tabular}

\section{CONCLUSIONS}

Gamification is an integral technique of many applications since this approach could help achieve promising results when integrated into any application. Effective and engaging learning and teaching techniques are essential. Applying the Gamification technique in difficult subjects is considered to be a highly valuable and challenging attempt. This study has identified the game elements that could be used in a learning material, which has further been validated by experts and students.

All participants agree to the use of these game elements but each has different perspectives regarding their usage such as to increase the level of fun and entertainment; as motivation to challenge other students; and to improve their skill of gaming and learning.

The game elements to increase the fun and entertainment level are Points, Scoring System, and Stars. On the other hand, the game elements to increase the motivation for students to challenge each other are Badges, Top 10, and Leaderboard. Whilst game elements to improve the skills of gaming and learning are Result, Report, Dashboard, Percentages of Competency, Progress Bar, Stage, Level, Countdown, Profile Information, Pictures, and Avatars.

In previous work, [8], [13], [14], [15], [18], [19], [27], [31]-[37] summarized the elements of games such as dynamic game elements and mechanic game elements without mentioning their functionality. Another side the viewpoints of two perspectives was same in the most of the game elements, but the different is students suggested using Badges, Top 10, and a Leaderboard to increase motivation to for students to challenge each other, and gamers suggested using Points, Scoring system, and Stars to increase the level of fun and entertainment, as highlighted in Table 7.

Finally, to enhance student understanding and learning, this study briefly touched on all Gamification elements based on previous research that would positively affect student understanding. This study presented the summary of Gamification elements that are verified by multiple users.

In the future, those elements would be applied in a learning application, and its effectiveness, motivation with the usability of learning application would be measured as pre-test and post-test in terms of student learning progress.

\section{ACKNOWLEDGMENT}

This work is supported by Multimedia Software and Usability Research Group at Faculty of Information Science and Technology, Universiti Kebangsaan Malaysia under FRGS/2/2014/ICT05/UKM/02/1 and DPP-2015-022 research grant.

\section{REFERENCES}

[1] S. Deterding, M. Sicart, L. Nacke, K. O'Hara, and D. Dixon, "Gamification. using game-design elements in non-gaming 
contexts," in CHI'11 Extended Abstracts on Human Factors in Computing Systems, 2011, pp. 2425-2428.

[2] S. Deterding, D. Dixon, R. Khaled, and L. Nacke, "From game design elements to gamefulness: defining gamification," in Proceedings of the 15th International Academic MindTrek Conference: Envisioning Future Media Environments, 2011, pp. 915.

[3] S. Deterding, R. Khaled, L. Nacke, and D. Dixon, "Gamification: Toward a definition," in CHI 2011 Gamification Workshop Proceedings, 2011, pp. 12-15.

[4] G. Zichermann and C. Cunningham, Gamification by design: Implementing game mechanics in web and mobile apps: O'Reilly Media, Inc., 2011.

[5] K. M. Kapp, The Gamification of Learning and Instruction Fieldbook: Ideas Into Practice: John Wiley \& Sons, 2013.

[6] Gartner. (2011, 25 Jun). Gartner Says By 2015, More Than 50 Percent of Organizations That Manage Innovation Processes Will Gamify Those Processes. Available: www.gartner.com/newsroom/id/1629214

[7] J. Thom, D. Millen, and J. DiMicco, "Removing gamification from an enterprise SNS," in Proceedings of the ACM 2012 Conference on Computer Supported Cooperative Work, 2012, pp. 1067-1070.

[8] J. Simões, R. D. Redondo, and A. F. Vilas, "A social gamification framework for a K-6 learning platform," Computers in Human Behavior, vol. 29(3), pp. 345-353, 2013.

[9] J. Hamari, "Transforming homo economicus into homo ludens: A field experiment on gamification in a utilitarian peer-to-peer trading service," Electronic Commerce Research and Applications, vol. 12(7), pp. 236-245, 2013.

[10] A. Domínguez, J. Saenz-de-Navarrete, L. de-Marcos, L. FernándezSanz, C. Pagés, and J.-J. Martínez-Herráiz, "Gamifying learning experiences: Practical implications and outcomes," Computers \& Education, vol. 63(4), pp. 380-392, 2013.

[11] J. Fernandes, D. Duarte, C. Ribeiro, C. Farinha, J. M. Pereira, and M. M. d. Silva, "iThink: A Game-Based Approach Towards Improving Collaboration and Participation in Requirement Elicitation," Procedia Computer Science, vol. 15, pp. 66-77, 2012.

[12] N. K. Cobb and J. Poirier, "Effectiveness of a Multimodal Online Well-Being Intervention: A Randomized Controlled Trial," American Journal of Preventive Medicine, vol. 46(1), pp. 41-48, 2014.

[13] Z. Kosmadoudi, T. Lim, J. Ritchie, S. Louchart, Y. Liu, and R. Sung, "Engineering design using game-enhanced CAD: The potential to augment the user experience with game elements," Computer-Aided Design, vol. 45(3), pp. 777-795, 2013.

[14] M. J. S. Broussard, "Using Games to Make Formative Assessment Fun in the Academic Library," The Journal of Academic Librarianship, vol. 40(1), pp. 35-42, 2012.

[15] J. L. Dickinson, R. L. Crain, H. K. Reeve, and J. P. Schuldt, "Can evolutionary design of social networks make it easier to be 'green'?," Trends in Ecology \& Evolution, vol. 28(9), pp. 561-569, 2013.

[16] F. H. Naeini and M. Masood, "Effect of Educational Computer Games on Student Creativity," Research Journal of Applied Sciences, Engineering and Technology, vol. 4, pp. 5280-5284, 2012.

[17] F. H. Naeini and B. Krishnam, "Usage Pattern, Perceived Usefulness and Ease of Use of Computer Games among Malaysian Elementary School Students," Research Journal of Applied Sciences, Engineering and Technology, vol. 4, pp. 5285-5297, 2012.

[18] I. Blohm, and J. M. Leimeister, "Design of IT-Based Enhancing Services for Motivational Support and Behavioral Change," Business and Information Systems Engineering, vol. 5 (4), pp. 275-278, 2013.

[19] A. F. Aparicio, F. L. G. Vela, J. L. G. Sánchez, and J. L. I. Montes, "Analysis and application of gamification," in Proceedings of the 13th International Conference on Interacción Persona-Ordenador, 2012, p. 17.

[20] F. L. Khaleel, N. S. Ashaari, T. S. Meriam, T. Wook, and A. Ismail, "The study of gamification application architecture for programming language course," in Proceedings of the 9th International Conference on Ubiquitous Information Management and Communication, 2015, p. 17

[21] F. L. Khaleel, N. S. Ashaari, T. S. Meriam, T. Wook, and A. Ismail, "User-Enjoyable Learning Environment Based on Gamification Elements," in International Conference on Computer, Communication, and Control Technology (I4CT 2015),, Kuching, Sarawak, Malaysia, 2015, p. 221.

[22] F. L. Khaleel, N. S. Ashaari, T. S. Meriam, T. Wook, and A. Ismail, "The Architecture of Dynamic Gamification Elements Based
Learning Content," Journal of Convergence Information Technology, vol. 11, pp. 164-177, 2016.

[23] J. Nielsen, Usability engineering: Elsevier, 1994.

[24] J. W. Creswell, Qualitative inquiry and research design: Choosing among five approaches: Sage, 2012.

[25] J. W. Creswell, Qualitative inquiry and research design: Choosing among five approaches: Sage, 2007.

[26] F. L. Khaleel, "Recruitment and Job Search Application," M.Sc. IT. thesis, Universiti Utara Malaysia, 2011.

[27] L. F. M. Ibharim, N. A. A. Zaki, and M. H. M. Yatim, "Touch gesture interaction of preschool children towards games application using touch screen gadjet," Asia-Pacific Journal of Information Technology and Multimedia, vol. 4, pp. 47-58, 2015.

[28] N. A. Matzin and W. SengYue, "Design and evaluation of history digital game based learning (DGBL) software," Journal of Next Generation Information Technology, vol. 4, p. 9, 2013.

[29] N. A. Matzin and W. S. Yue, "History educational games design," in International Conference on Electrical Engineering and Informatics ICEEI, 2009, pp. 269-275

[30] N. A. Matzin, W. S. Yue, and A. Jaafar, "Digital game-based learning (DGBL) model and development methodology for teaching history," WSEAS Transactions on Computers, vol. 8, pp. 322-333, 2009.

[31] F. Kayali, M. Silbernagl, K. Peters, R. Mateus-Berr, A. Reithofer, D. Martinek, et al., "Design considerations for a serious game for children after hematopoietic stem cell transplantation," Entertainment Computing, vol. 15, pp. 57-73, 2016.

[32] M. Pirovano, E. Surer, R. Mainetti, P. L. Lanzi, and N. A. Borghese, "Exergaming and rehabilitation: A methodology for the design of effective and safe therapeutic exergames," Entertainment Computing, vol. 14 , pp. 55-65, 2016.

[33] A. Moreno, R. van Delden, R. Poppe, D. Reidsma, and D. Heylen, "Augmenting playspaces to enhance the game experience: A tag game case study," Entertainment Computing, 2016.

[34] M. M. Van der Wal, J. de Kraker, C. Kroeze, P. A. Kirschner, and P. Valkering, "Can computer models be used for social learning? A serious game in water management," Environmental Modelling \& Software, vol. 75, pp. 119-132, 2016.

[35] K. Mikami, Y. Nakamura, A. Ito, M. Kawashima, T. Watanabe, Y. Kishimoto, et al., "Effectiveness of Game Jam-based iterative program for game production in Japan," Computers \& Graphics, 2016.

[36] D. A. Mawhirter and P. F. Garofalo, "Expect the Unexpected: Simulation Games as a Teaching Strategy," Clinical Simulation in Nursing, vol. 12, pp. 132-136, 2016.

[37] O. Ku, C.-C. Hou, and S. Y. Chen, "Incorporating customization and personalization into game-based learning: A cognitive style perspective," Computers in Human Behavior, vol. 65, pp. 359-368, 2016 